\title{
Perhitungan Potensi Energi Listrik Pada Sekam Padi Melalui Metode Gasifikasi
}

\author{
Umar Faruq Al-afifi ${ }^{1}$, Elvin Piter ${ }^{2}$, Erdin Syam ${ }^{3}$ \\ ${ }^{1,2,3}$ Program Studi Teknik Elektro Fakultas Teknik Universitas Mulawarman. \\ Jl. Sambaliung No.9, Sempaja Selatan, Samarinda, Kalimantan Timur Telp. (0541) 75117 \\ Email : umarfaruq802@ymail.com
}

\begin{abstract}
Abstrak
Sejak pertama kali ditemukannya Minyak bumi, Pemakaian Minyak bumi sebagai bahan bakar terus menunjukan peningkatan yang luar biasa dari waktu ke waktu, Sebagai subsidi untuk transportasi atau untuk tujuan lainnya, riset membuktikan bahwa dikhawatirkan energi minyak bumi yang berasal dari fosil akan habis dalam waktu dekat, hal ini memunculkan berbagai inovasi baru terutama dalam menciptakan bahan bakar baru yang berfungsi sama selayaknya energi fosil, dalam hal ini diperkenalkanlah Biomassa yaitu energi yang berasal dari limbah nabati, yang menjadikan energi ini tidak hanya sebagai alternatif dan hemat tetapi juga membantu membersihkan limbah di Bumi. Biomassa dapat dipergunakan sebagai Bahan Konversi Energi dalam Pembangkit Listrik yang berbahan dasar Biomassa melalui berbagai teknologi. Pada jurnal ini teknologi PLTBM yang digunakan adalah Gasifikasi pada sekam padi. Dalam perancangan gasifikasi ini divisualkan dengan berbasis simulasi dan berdasarkan penelitian yang telah dilakukan di PLTD Biomassa Indramayu. Berdasarkan produksi padi di kab.Maros tahun 2016 yaitu 202.000 ton, akan menghasilkan sekitar 40.000 ton sekam padi yang setelah dimanfaatkan akan didapatkan sekitar 17.466,22 MW. Pada penelitian ini energi listrik dihasilkan dari nilai kalor dari padi setelah proses Gasifikasi yang berbentuk Msyngas. Dengan Msyngas inilah yang memberikan Energi Mekanik kepada turbin dalam memberikan stimulus kepada generator untuk menghasilkan listrik.
\end{abstract}

Kata Kunci: Terbarukan, PLTBM, Gasifikasi, Sekam Padi

\begin{abstract}
Since the first discovery of petroleum, the use of petroleum as fuel has continued to show remarkable increases over time. As a transportation subsidy or for other purposes, research shows that it is feared that petroleum energy derived from fossils will be used up in the near future, things This has led to new innovations, especially in creating new fuels that function just as fossil energy, in this case Biomass is introduced, which is energy derived from vegetable waste, which makes this energy not only as an alternative and economical but also helps clean up waste on Earth. Biomass can be used as an Energy Conversion Material in Power Plants that are based on Biomass through various technologies. In this journal the PLTBM technology used is gasification in rice husks. In this gasification desain, it is visualized on the basis of simulation and based on research that has been done at the Indramayu Biomass PLTD. Based on rice production in Maros regency in 2016 which is 202,000 tons, will produce around 40,000 tons of rice husk which after being utilized will get around 17,466.22 MW. In this study, electrical energy is produced from the heating value of rice after the gasification process in the form of Msyngas. With Msyngas this is what gives Mechanical Energy to the turbine in providing stimulus to the generator to produce electricity.
\end{abstract}

Keywords: Renewable, PLTBM, Gasification, Rice Husk

\section{PENDAHULUAN}

Sejak pertama kali Minyak Bumi ditemukan oleh manusia, Minyak bumi seolah menggantikan energi apapun dan menjadi energi vital dalam setiap objek pekerjaan manusia, Sebagai bahan bakar moda transportasi Manusia maupun untuk energi dengan tujuan yang 
lainnya. Hal ini tentu memiliki dampak yaitu akan terjadi kekosongan berdasarkan riset energi fosil dalam waktu dekat dikarenakan pemakaian yang kian meningkat dari waktu ke waktu. Ditambah lagi dengan Isu harga BBM yang tidak kunjung stabil dari waktu ke waktu yang dipengaruhi harga minyak dunia yang fluktuatif di dekade ini dikarenakan berbagai krisis krisis bermunculan sehingga hal ini sangat mempengaruhi ketersediaan penggunaan Energi Fosil karena sifatnya yang Non-Renewable [1]. Penggunaan Energi Fosil yang memiliki emisi gas Rumah kaca yang cukup besar dikarenakan penggunaanya yang terus meningkat memaksa para ilmuwan untuk Energi terbarukan yang tidak hanya dapat menjadi pengganti energi Fosil namun juga memiliki sifat Ramah lingkungan salah satunya adalah Biomassa [2].

Proyeksi untuk mencari energi yang mengandung Hidrogen, gas alami, Bio-Oil, biogas, alkohol dan biodiesel semakin gencar dilakukan karena diketahui semua kandungan tersebut dapat ditemukan didalam Biomassa [3]. Biomassa dianalogikan sebagai suatu limbah atau ampas dari hasil suatu kegiatan produksi pertanian. Pemanfaatan Biomassa dipicu karena proses penguraian dan penghancuran limbah hasil pertanian prosesnya sangatlah lambat dan dapat menganggu lingkungan dan Kesehatan manusia [4].

Proses konversi energi Biomassa dilakukan dengan fokus utama yaitu mengambil kandungan $\mathrm{CH} 4$ dari Biomassa itu sendiri dengan melalui proses fermentasi metabolism ditambahkan dengan kandungan $\mathrm{O} 2$ atau oksigen hal ini akan memberi dampak berupa keluarnya $\mathrm{CH} 4$ dari Biomassa setelah melalui Anaerobik proses [3]. Hal ini yang sudah diterapkan diberbagai proyek pemanfaatan energi terbarukan diberbagai tempat yang memfokuskan topik utamanya pada biomassa yang kemudian akan dikonversi menjadi energi listrik salah satunya, yang lebih dikenal dengan Pembangkit Listrik tenaga Biomassa menggunakan Teknologi yang disebut sebagai Gasifikasi yang memfokuskan pengambilan gas dari biomassa melalui proses Fermentasi untuk kemudian dijadikan sebagai energi listrik nantinya.

Proses pengkonversian Energi Biomassa menjadi Energi terbarukan atau dalam konteks ini adalah Energi Listrik salah satunya dengan cara Gasifikasi Biomassa, karena dengan teknologi ini dapat dilakukan pengkonversian Biomassa dalam jumlah besar dalam waktu yang cepat, untuk kemudian diambil campuran gas didalamnya seperti Hidrogen, Carbon dan HidroCarbon yang menguap secara alami melalui proses Fermentasi bersamaan dengan Nitrogen dan Karbon Dioksida dalam tabung [2].

Proses Gasifikasi yaitu Suatu proses pengambilan energi Biomassa yang kemudian dikonversi dan dibentuk menjadi energi gas yang bisa disebut dengan Msyngas yang terdiri dari Hidrogen, Carbon, Metana yang mana dengan Msyngas inilah bisa didapatkan energi kalor dari Biomassa [1], [5].

Peluang pemanfaat Biomassa salah satunya terletak pada Limbah hasil Pertanian yaitu Padi, karena proses pengolahannya yang fleksibel dan juga selalu tersedia Hasil Limbah pertanian yang cukup besar dari hari kehari. Peluang pemanfaatan Limbah padi terletak pada bagian Limbah berupa Sekam padi yang dinilai berpotensi memiliki kandungan sumber bahan bakar karena memiliki kandungan silika yang tinggi untuk dimanfaatkan dalam berbagai kepentingan [6]. Berikut secara umum kandungan dari Sekam padi per kilogramnya.

Tabel 1. Kandungan dan nilai kalor biomassa sekam padi per kilonya

\begin{tabular}{cc}
\hline Kandungan Biomassa & Nilai \\
\hline $\mathbf{C}$ & $55,4 \%$ \\
$\mathbf{H}$ & $20,1 \%$ \\
$\mathbf{N}$ & $11,3 \%$ \\
$\mathbf{O}$ & $13,2 \%$ \\
$\mathbf{C H 4}$ & $1,8 \%$ \\
HHV & $5059,23 \mathrm{KJ} / \mathrm{Kg}$ \\
LHV & $1819,23 \mathrm{KJ} / \mathrm{Kg}$ \\
Density & $617 \mathrm{Kg} / \mathrm{m}^{3}$ \\
Konversi karbon & $62 \%$ \\
\hline
\end{tabular}

Maka dengan adanya Perancangan berbasis Simulasi berdasarkan data Real yang diambil dari PLTBM indramayu, harapannya Simulasi ini akan bisa diterapkan secara Real di daerah daerah yang memiliki pengolahan padi yang cukup besar, salah satunya disini akan coba diterapkan melalui data pengolahan padi di Kabupaten Maros, yang mana menghasilkan Olahan padi yang cukup besar per tahunnya begitu juga dengan Limbah Padinya tentunya, Contoh Real nya seperti di tahun 2016, Kabupaten Maros menghasilkan padi sebanyak 202.000 ton, dan menghasilkan limbah padi 
SainETIn (Jurnal Sain, Energi, Teknologi \& Industri), Vol. 4 No. 2, Juni 2020, pp. 48 - 56

ISSN 2548-6888 print, ISSN 2548-9445 online

sebanyak 40.400 ton [1], dari besarnya Limbah padi ini harapannya bisa memberikan ketersediaan Energi Listrik yang cukup besar untuk Kabupaten Maros nantinya, jika Simulasi ini akan direalisasikan suatu hari nanti.

\section{METODE PENELITIAN}

Indonesia adalah suatu negara dengan Nasi sebagai makanan pokoknya, diseluruh Indonesia Beras menjadi kebutuhan pokok primer bagi seluruh rakyat Indonesia, sehingga hal ini menjadikan Produksi padi setiap waktunya tidak akan berhenti dengan produksi yang sangat besar, dan hal ini juga memicu produksi limbah pertanian padi yang cukup besar pula. Berdasarkan data BPS Indonesia menghasilkan Limbah padi berupa sekam padi sebesar $22 \%$ dari setiap kegiatan pengolahan padi [1]. Maka dengan adanya limbah berupa sekam padi memberikan adanya harapan potensi untuk dikembangkan menjadi energi terbarukan yang tentu juga ramah lingkungan serta bisa menjadi bahan bakar untuk pembangkit listrik yang tentu dapat menghasilkan Energi Listrik di setiap daerah pengolahan padi dengan melalui Pembangkit Listrik Tenaga Biomassa (PLTBM).

\section{A. Teknologi Rancangan}

Proses Pengkonversian Biomassa menjadi Energi Listrik dalam PLTBM menggunakan salah satu teknologi bernama Gasifikasi, Proses Gasifikasi ini diperuntukan untuk mendapatkan Energi Gas dan Kalor yang terkandung didalam biomassa, proses Gasifikasi memiliki 4 tahapan yaitu [7]-[9]:

1. Tahap Pengeringan : Tahap dimana Sekam padi akan dikeringkan secara total dengan menggunakan Panas yang bersumber dari Reaksi Oksidasi.

2. Tahap Pirolisa : Tahap dimana sekam padi yang telah habis kadar airnnya akan kembali dipanaskan dengan derajat suhu yang lebih tinggi bertujuan untuk mengubah sekam padi menjadi zat hitam lain berupa arang dan tar sebagai ampasnya dan Msyngas yaitu gas hasil pemanasannya.

3. Tahap Oksdasi: Tahap dimana Sekam padi yang telah dipirolisa akan teroksidasi dengan kandungan oksigen dari udara yang masuk kedalam tabung oksidasi, sehingga akan muncul panas alami yang muncul dari Sekam padi yang mana panas tersebut akan digunakan pada tahap pengeringan.

4. Tahap reduksi : Tahap dimana sekam padi yang telah teroksidasi sembari mengeluarkan Energi panas alami yang berbentuk kalor utama yang dapat dimanfaatkan untuk pengkonversian energi tahap selanjutnya.

Dalam PLTBM atau Pembangkit Listrik Tenaga Diesel yang menggunakan Teknologi Gasifikasi, pasti menggunakan Energi Kalor yang memiliki tekanan gas yang bisa disebut sebagai Msyngas, dengan Msyngas inilah Turbin dari Pembangkit Listrik dapat bergerak. Berdasarkan Gambar 1.

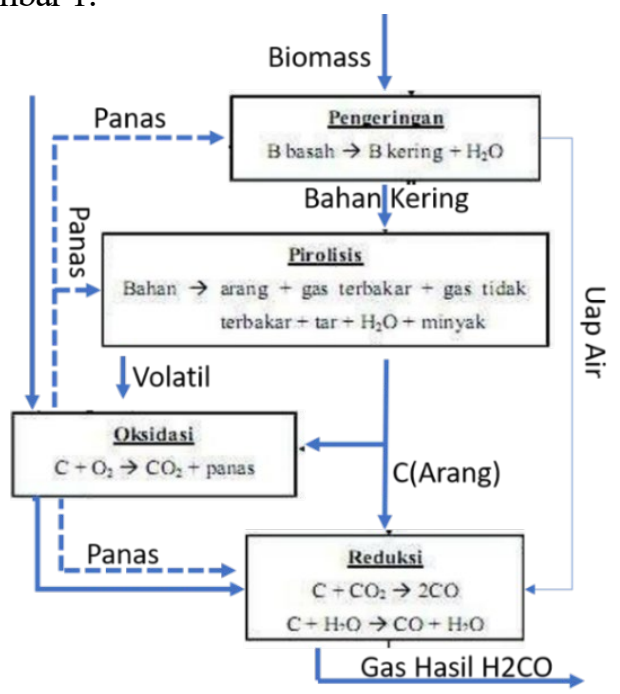

Gambar 1. Blok Diagram Proses Gasifikasi

Pada blok diagram Gambar 1, Msyngas dapat disebut sebagai H2CO. Selayaknya PLTU yang digerakan oleh Uap, did alam PLTBM Gas H2CO lah yang menjadi penggeraknya.



Gambar 2. Blok Diagram Proses PLTBM 
SainETIn (Jurnal Sain, Energi, Teknologi \& Industri), Vol. 4 No. 2, Juni 2020, pp. 48 - 56

ISSN 2548-6888 print, ISSN 2548-9445 online

Gas Hasil Gasifikasi yaitu $\mathrm{H} 2 \mathrm{CO}$ selanjutnya akan menjadi Langkah awal dalam proses pengkonversiannya menjadi energi listrik. Namun sebelum berlanjut untuk menjalankan tugasnya untuk memutar Turbin, ternyata Turbin dalam pembangkit Listrik memiliki Kadar Standar minimum yang dapat menggerakkan turbin tersebut. Seperti yang diketahui dalam PLTBM atau PLTD Gasifikasi, sama selayaknya PLTG atau PLTU pada umunya yang juga memakai Turbin Uap. Standar Minimum dari suatu gas untuk dapat memutar turbin yaitu memiliki kandungan $\mathrm{H} 2 \mathrm{O}$ yang cukup dominan, sehingga Msyngas dari hasil gasifikasi masih belum memnuhi standar.

Maka dari itu Gas Hasil Gasifikasi selanjutnya akan diberikan tambahan elemen H2O dengan cara Water Shift Gas Reaction. Water Shift Gas Reaction atau pemurnian yaitu Reaksi untuk menambah kandungan $\mathrm{H}_{2} \mathrm{O}$ dengan cara menguapkan Air menjadi Uap air yang kemudian memberikan kekuatan tambahan untuk Msyngas atau bisa disebut sebagai proses Pemurnian $\mathrm{Gas}_{2} \mathrm{CO}$ sehingga dapat memutar turbin.

$$
\mathrm{CO}+\mathrm{H}_{2} \mathrm{O} \longrightarrow \mathrm{CO}_{2}+\mathrm{H}_{2}
$$

Setelah dilakukan pemurnian barulah Gas memenuhi syarat untuk dapat memutar turbin, dan turbin memicu pergerakan generator dan akhirnya listrik dapat dihasilkan. Sebagaimana diilustrasikan pada Gambar 3.

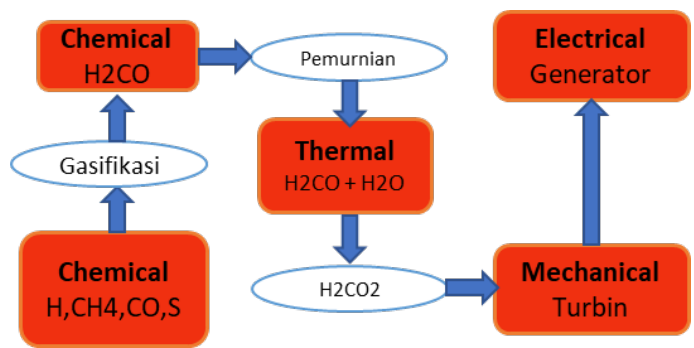

Gambar 3. Proses pengkonversian Energi

Dalam Tabel.2 terlihat bahwa sekam padi memiliki kandungan yang luar biasa untuk dimanfaatkan sebagai energi terbarukan dan dikonversi menjadi energi apa saja, dan dalam konteks ini dikonversi kepada Energi Listrik. Dalam proses Gasifikasi Sekam Padi selain dipicu oleh kandungan gas yang cukup banyak namun juga dipicu karena gas gas tersebut mengandung dan membawa kandungan Kalor yang cukup besar untuk dimanfaatkan, bahkan kandungan kalor dalam sekam padi menjadi tempat dengan kalor terbesar dibandingkan dengan bagian lain dalam tanaman padi lainnya. Tabel 2 berikut memperlihatkan komposisi Energi Kalor dalam tanaman padi [10].

Tabel 2. Komposisi dari limbah Biomassa pertanian berupa Padi

\begin{tabular}{cll}
\multicolumn{2}{c}{ Limbah Biomassa } & Kalor Jenis \\
padi & Sekam & $3300 \mathrm{kKal} / \mathrm{kg}$ \\
& Jerami & $2800 \mathrm{kKal} / \mathrm{kg}$ \\
& Merang & $3200 \mathrm{kKal} / \mathrm{kg}$
\end{tabular}

Selain itu juga Sekam padi juga diketahui juga memiliki kadar air sebesar $0 \%$ yang dapat memicu besarnya energi kalor yang terkandung didalam sekam padi. Berdasarkan calorimeter diproleh High Heating Value (HHV) yaitu potensi nilai pembakaran dari Sekam padi menempati peringkat ketiga setelah serbuk kayu dan arang, sehingga berdasarkan hal tersebut memberikan nilai lebih untuk Sekam padi dimanfaatkan sebagai bahan bakar energi terbarukan [11]. Berdasarkan kadar Kalor yang diketahui paling tinggi terdapat pada sekam padi, maka dalam hal ini dapat dilakukan pengkonversian secara perhitungan Real berdasarkan persamaan energi sederhana [12] yaitu :

$$
\begin{aligned}
& 1 \text { kalori }=4,2 \text { joule } \\
& \text { Maka: } \\
& 1 \text { joule } \quad=1 / 4,2=0,24 \text { kalori } \\
& \text { Sehingga } \\
& 1 \mathrm{kkal}=1000 \times 4,2 \text { joule } \\
& =4200 \text { joule, atau } 4,2 \text { kilojoule. }
\end{aligned}
$$

Selanjutnya, jumlah perbandingannya adalah sebagaimana terlihat pada Tabel 3 berikut :

Tabel 3. Konversi Kalor ke joule dari limbah Biomassa pertanian berupa Padi

\begin{tabular}{lcl}
\hline \multicolumn{2}{c}{ Limbah Biomassa } & Kalor Jenis \\
\hline Sekam & $3300 \mathrm{kKal} / \mathrm{kg}$ & $13,86 \times 10^{6} \mathrm{~J} / \mathrm{kg}$ \\
Jerami & $2800 \mathrm{kKal} / \mathrm{kg}$ & $11,76 \times 10^{6} \mathrm{~J} / \mathrm{kg}$ \\
Merang & $3200 \mathrm{kKal} / \mathrm{kg}$ & $13,44 \times 10^{6} \mathrm{~J} / \mathrm{kg}$ \\
\hline
\end{tabular}

Berdasarkan tabel diatas dapat diketahui angka dari masing masing bagian yang memiliki tingkat energi panas terbanyak dan tertinggi, 
SainETIn (Jurnal Sain, Energi, Teknologi \& Industri), Vol. 4 No. 2, Juni 2020, pp. 48 - 56

ISSN 2548-6888 print, ISSN 2548-9445 online

yang mana dengan diketahuinya hal tersebut menguatkan pilihan dalam memilih sekam padi untuk dimanfaatkan energi joule nya untuk dikonversi menjadi energi listrik melalui proses Teknologi yang dinamakan Gasifikasi. Melalui perhitungan secara Real melalui persamaan Energi sejenis maka dapat kita kalkulasikan potensi pemanfaatan Biomassa menjadi energi listrik yaitu :

$$
\mathrm{W}=\mathrm{P} \times \mathrm{t}
$$

$\mathrm{W}=$ Energi Listrik(Joule $)$

$\mathrm{P}=$ Daya $(\mathrm{W})$

$\mathrm{t}=$ Waktu$(\mathrm{S})$

Ex :

$\mathrm{P}=1000$ Watt

$\mathrm{t}=1 \mathrm{jam}=3600$ detik

$\mathrm{W}=1000$ watt $\times 3600$ detik

$=3600000$ Watt.detik

$1 \mathrm{kwH}=3,6 \times 10^{6}$ Joule

\section{B. Metode Rancangan}

Pemilihan tekonologi yang tepat dalam proses mengolah limbah padi menjadi bahan bakar yang dapat dikonversi menjadi energi listrik sangatlah penting. Hal ini juga didasari agar output daya yang diinginkan dapat tercapai tanpa kendala yang besar. Pemilihan teknologi berdasarkan studi penelitian mengenai pembangkit listrik tenaga diesel - Biomassa di kabupaten Indramayu dan pengolahan penggilingan padi di Daerah maros, Sulawesi Selatan. Jenis gasifikasi yang digunakan adalah downdraft gasifier yang mana hal ini juga penting untuk memilih reaktor yang sesuai agar bisa berjalan sesuai dengan blok diagram pada Gambar 8.

\section{Merancang Desain Visual PLTBM}

Perancangan pada pemodelan PLTBM dalam skala besar biasanya melibatkan Steam dan juga turbin, yang mana Model dari PLTBM itu sendiri dapat digunakan untuk skala besar, Namun pada jurnal ini akan dipaparkan berupa model PLTBM versi Sederhana namun Esensi dari pembangkitan Listrik menggunkan bantuan dari Tenaga Biomassa yaitu tetap ada. Perancangan Desain Visual PLTBM dilakukan secara bertahap yang pertama adalah dengan memasukkan blok diagram Gasifikasi kedalam Blok Diagram proses Pembangkit Listrik Tenaga Biomassa. Langkah pertama yaitu merancang desainnya dilakukan secara manual yaitu tulis tangan dan aplikasi Power Point untuk membuat
Blok Diagramnya, sebagaimana terlihat pada Gambar 9.

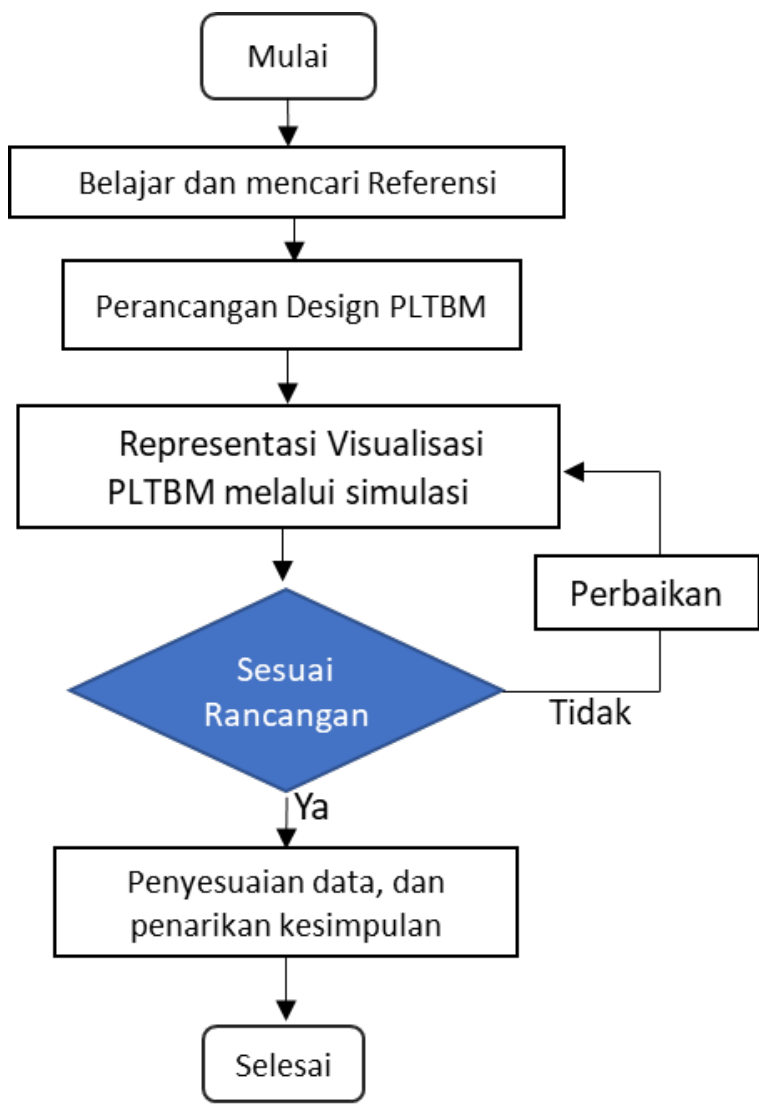

Gambar 8. Blok diagram Rancangan



Gambar 9. Perancangan Desain

\section{Representasi Visualisasi PLTBM melalui Simulasi}

Proses Implementasi Desain yang telah dibuat, dituangkan kedalam sebuah media karya, baik itu melalui prototype atau simulasi dengan media aplikasi. Pada jurnal ini dipilih media karya yaitu Simulasi melalui Aplikasi. Aplikasi yang digunakan disini adalah aplikasi bernama SketchUp 2018. Bentuk dari media tersebut adalah sebagaimana terlihat pada Gambar 10. 




\section{Pengujian Simulasi}

Pengujian Simulasi dilakukan dengan menggunakan data produksi Padi di suatu Kabupaten yaitu kabupatern Maros, yang dimana disana belum ada pemanfaatan Limbah padi yaitu Sekam padi untuk diubah menjadi energi listrik, padahal di Kabupaten tersebut menghasilkan produksi Padi dan Limbah padi yang luar biasa sehingga dengan pengambilan data dari produksi padi di kabupaten maros akan dijadikan sebagai contoh kasus dalam perhitungan potensi energi Limbah Biomassa berupa sekam padi di daerah tersebut. Tabel 4 memperlihatkan rata-rata produksi padi dan limbah pertahunnya.

Tabel 4. Rata rata produksi padi dan limbah per tahunnya di kabupaten Maros

\begin{tabular}{cccc}
\hline No. & Tahun & $\begin{array}{c}\text { Produksi } \\
\text { Padi(ton) }\end{array}$ & $\begin{array}{c}\text { Produksi } \\
\text { Sekam } \\
\text { padi(ton) }\end{array}$ \\
\hline $\mathbf{1}$ & 2016 & 202.000 & 40.400 \\
$\mathbf{2}$ & 2017 & 226.000 & 45.200 \\
$\mathbf{3}$ & 2018 & 273.000 & 54.600 \\
$\mathbf{4}$ & 2019 & 268.000 & 53.600 \\
\hline \multicolumn{4}{l}{ Sumber BPS Maros 2016-2019 }
\end{tabular}

\section{Pengambilan data}

Setelah Proses Perancangan dan Pembuatan Simulasi selesai, maka dilakukan pengujian yang diharapkan bisa sesuai dengan perancangan. Dalam proses pengujian disini akan dilakukan pengambilan data perhitungan yang berdasarkan beberapa parameter penting dalam Pembangkit Listrik Tenaga Biomassa (PLTBM) yaitu :

\section{Fuel Consumption Rate(FCR)}

Adalah kadar tingkatan Konsumsi Bahan bakar yang prosesnya dilakukan didalam Ruang
Pembakaran, dan dalam hal ini bahan bakar yang dibakar adalah Sekam padi untuk diambil gas $\mathrm{H} 2 \mathrm{CO}$ nya.

$$
\mathrm{FCR}=\frac{\text { massa }}{\text { Waktu }}(\mathrm{kg} / \mathrm{Jam})
$$

\section{Massa Jenis Campuran Kimia}

Adalah Massa Jenis dari setiap Zat Kimia yang terkandung dalam Sekam padi, Lihat di Tabel.1 untuk melihat persentase per Kilogramnya.

$$
\begin{aligned}
\rho \operatorname{Mix}= & (\rho \mathrm{C} \times \% \mathrm{C})+(\rho \mathrm{H} \times \% \mathrm{H})+ \\
& (\rho \mathrm{N} \times \% \mathrm{~N})+(\rho \mathrm{CH} 4 \times \mathrm{CH} 4)
\end{aligned}
$$

\section{Massa Gas Hasil Gasifikasi}

bisa disebut Msyngas adalah Massa dari Gas hasil Gasifikasi yang telah dipanaskan dan dikalikan dengan Massa Jenis Campuran untuk disesuaikan kadar Kimia sebelum dan sesudah proses Gasifikasi.

$$
\text { Msyngas }=\rho \text { Mix x Sekam padi }
$$

\section{Efisiensi Gasifikasi}

Adalah kadar efisiensi berdasarkan Kadar LHV dan HHV yang masing masing dijumlahkan dengan Massa Total dari Syngas dan Massa total Biomassa yang digunakan.

$$
\text { ๆg } 2016=\frac{\text { M.Syngas } \times L H V}{\text { M.Biomass } \times H H V} \times 100 \%
$$

Kalor Sekam padi

$$
\mathrm{Q}=\text { Msyngas } \mathrm{x} \text { LHV }
$$

\section{HASIL DAN PEMBAHASAN}

Dari pengamatan dan penelitian yang dilakukan dengan menggunakan contoh kasus pengambilan data dari produksi padi di kabupaten maros kemudian dilakukan perhitungan manual dengan tujuan memaparkan potensi energi biomassa berupa sekam padi yang dapat diubah menjadi energi listrik dan berdasarkan dari tabel 4 diatas, didapat biomassa yang dapat diolah per tahunnya adalah sebesar 40.400 ton per tahun. Dari angka tersebut jika kita korelasikan dengan Tabel 3, Untuk mencari massa syngasnya didapatlah

$$
\begin{aligned}
& \text { Fuel Consumtion Rate (FCR) } \\
& \mathrm{FCR}=\frac{M}{t}(\mathrm{~kg} / \mathrm{jam}) \\
& \mathrm{FCR}=\frac{2000 \mathrm{~kg}}{8 \mathrm{Jam}}=250 \mathrm{~kg} / \mathrm{jam} \\
& \rho M i x=\rho C \times \% C+\rho H \times \% H+\rho N \times \% N+ \\
& \text { مCH4 x CH4 }
\end{aligned}
$$


SainETIn (Jurnal Sain, Energi, Teknologi \& Industri), Vol. 4 No. 2, Juni 2020, pp. 48 - 56

ISSN 2548-6888 print, ISSN 2548-9445 online

$$
\begin{aligned}
\rho \operatorname{Mix}= & (1,25 \times 55,4 \%)+(0,09 \times 20,1 \%+ \\
& (1,25 \times 11,3 \%)+(0,68 \times 1,8 \%) \\
\rho \operatorname{Mix}= & 0,6925+0,01809+0,14125+ \\
& 0,01224 \\
\rho \text { Mix }= & 0,86408 \mathrm{Kg}
\end{aligned}
$$

Jika Massa Syngas dari sekam padi telah didapat maka produksi syngas berdasarkan table produksi Biomassa diatas adalah

Msyngas $\quad=\rho$ Mix $x$ Produksi Sekam Padi

$=0,86408 \mathrm{Kg} \times$ Produksi Sekam

Untuk tahun 2016

Msyngas

$$
\begin{aligned}
& =\rho \text { Mix } x \text { Produksi Sekam Padi } \\
& =0,86408 \mathrm{Kg} \times \text { Produksi Sekam } \\
& =0,86408 \mathrm{Kg} \times 44400 \text { ton } \\
& =34563,2 \mathrm{ton}
\end{aligned}
$$

Dengan cara yang sama dilakukan untuk memperoleh hasilnya pada tahun-tahun berikutnya, seperti Tabel 5 .

Tabel 5. Rata rata Produksi Syngas

\begin{tabular}{cccc}
\hline No. & Tahun & $\begin{array}{c}\text { Produksi } \\
\text { Sekam } \\
\text { padi(ton) }\end{array}$ & $\begin{array}{c}\text { Msyngas } \\
\text { (ton) }\end{array}$ \\
\hline $\mathbf{1}$ & 2016 & 40.400 & $34.563,2$ \\
$\mathbf{2}$ & 2017 & 45.200 & $39.056,41$ \\
$\mathbf{3}$ & 2018 & 54.600 & $47.178,76$ \\
$\mathbf{4}$ & 2019 & 53.600 & $46.314,68$ \\
\hline
\end{tabular}

Sumber : Hasil Perhitungan

Setelah memperoleh nilai dari syngas selanjutnya adalah menghitung nilai kalor dari hasil pembakaran biomassa Sekam padi dengan mengalikan Syngas dengan nilai kalor dari 1 ton Syngas (LHV) yang ada pada Tabel 3.

$\mathrm{Q}=$ Msyngas $\mathrm{x}$ LHV

$\mathrm{Q}=34563,2 \times 1819,23 \mathrm{KJ} / \mathrm{Kg}$

Dan diperoleh hasil seperti pada Tabel 6

Tabel 6. Rata rata nilai kalor per tahunnya

\begin{tabular}{cccc}
\hline Tahun & $\begin{array}{c}\text { Produksi } \\
\text { Sekam } \\
\text { padi } \\
\text { (ton) }\end{array}$ & $\begin{array}{c}\text { Msyngas } \\
\text { (ton) }\end{array}$ & $\begin{array}{c}\text { Nilai Kalor } \\
\text { (MJ) }\end{array}$ \\
\hline $\mathbf{2 0 1 6}$ & 40.000 & $34.563,2$ & $62.878,4$ \\
$\mathbf{2 0 1 7}$ & 45.200 & $39.056,41$ & $71.052,5$ \\
$\mathbf{2 0 1 8}$ & 54.600 & $47.178,76$ & $85.829,01$ \\
$\mathbf{2 0 1 9}$ & 53.600 & $46.314,68$ & $84.257,05$ \\
\hline
\end{tabular}

selanjutnya dengan adanya Msyngas sebagai penggerak turbin, dengan elemen didalamnya yang juga terdiri dari kalor, sehingga energi kalor dari Msyngas inilah yang bertindak sebagi Energi mekanik dari Msyngas terhadap turbin Generator, sehingga jika dikonversikan berdasarkan energi kalor dari Msyngas, dapat dikalkulasikan Daya listrik yang dapat dihasilkan oleh Generator adalah sebagai berikut:

$\mathbf{W}=\mathbf{P} \times \mathbf{t}$

Ex:

$\mathrm{P}=1000$ Watt

$\mathrm{t}=1 \mathrm{jam}=3600$ detik

$1 \mathrm{kwh}=1000$ watt $\times 3600$ detik $=3600000$ Watt.detik

$1 \mathrm{kwh}=3,6 \times 10^{6} \mathrm{Joule}$

Maka :

$$
=62.878,4 \mathrm{MJ}: 3.600 .000 \text { Joule }
$$

Adapun hasilnya adalah seperti pada Tabel 7 dan Gambar 11

Tabel 7. Rata rata produksi Listrik per tahunnya

\begin{tabular}{cccc}
\hline Tahun & $\begin{array}{c}\text { Msyngas } \\
\text { (ton) }\end{array}$ & $\begin{array}{c}\text { Nilai Kalor } \\
\text { (MJ) }\end{array}$ & P(MW) \\
\hline $\mathbf{2 0 1 6}$ & $34.563,2$ & $62.878,4$ & $17.466,22$ \\
$\mathbf{2 0 1 7}$ & $39.056,41$ & $71.052,5$ & $19.736,83$ \\
$\mathbf{2 0 1 8}$ & $47.178,76$ & $85.829,01$ & $23.841,39$ \\
$\mathbf{2 0 1 9}$ & $46.314,68$ & $84.257,05$ & $23.404,73$ \\
\hline
\end{tabular}

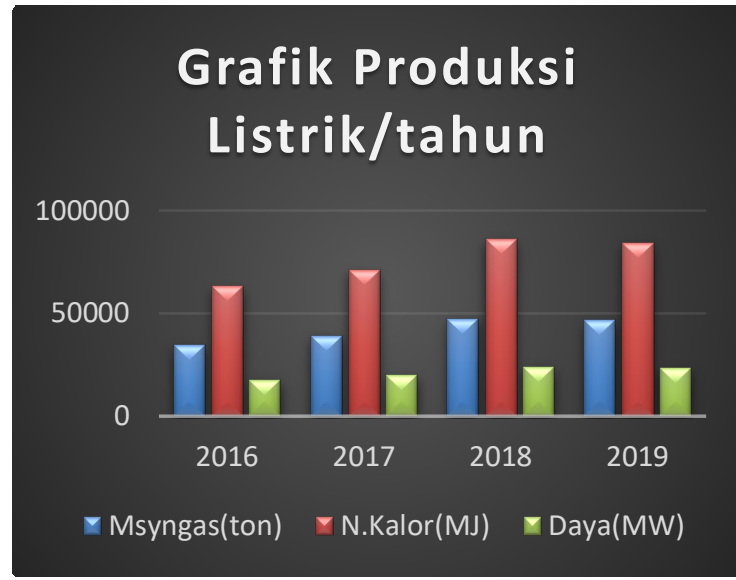

Gambar 11. Grafik Produksi Listrik per tahun di Kabupaten Maros

Nilai Gasifikasi spesifik untuk sekam padi dapat diproleh dari Tabel 7 diatas dimana nilai dari HHV Sekam padi adalah $5059,23 \mathrm{KJ} / \mathrm{Kg}$ dan Nilai LHV sekam padi adalah 1819,23 $\mathrm{KJ} / \mathrm{Kg}$ dengan Nilai efisiensi sekam padi yaitu: 
SainETIn (Jurnal Sain, Energi, Teknologi \& Industri), Vol. 4 No. 2, Juni 2020, pp. 48 - 56

ISSN 2548-6888 print, ISSN 2548-9445 online

$$
\begin{aligned}
\eta g \text { 2016 } & =\frac{\text { M.Syngas } \times \mathbf{L H} \boldsymbol{H}}{\text { M.Biomass } \times \boldsymbol{H} \boldsymbol{H} \boldsymbol{V}} \times \mathbf{1 0 0} \% \\
& =\frac{34.563 .200 \times 1819,23}{40.000 .000 \times 5059,23} \times 100 \% \\
& =\frac{62.878 .410 .336}{202.369 .200 .000} \times 100 \% \\
& =0,3107113649 \times 100 \% \\
& =31,07 \%
\end{aligned}
$$

Adapun hasilnya efisiensi produksi pertahunnya adalah seperti pada Tabel 8

Tabel 8. Efisiensi Produksi

\begin{tabular}{cccc}
\hline Tahun & $\begin{array}{c}\text { Produksi } \\
\text { Sekam } \\
\text { padi(ton) }\end{array}$ & $\begin{array}{c}\text { Msyngas } \\
\text { (ton) }\end{array}$ & Efisiensi \\
\hline $\mathbf{2 0 1 6}$ & 40.400 & $34.563,2$ & $31,07 \%$ \\
$\mathbf{2 0 1 7}$ & 45.200 & $39.056,41$ & $31,07 \%$ \\
$\mathbf{2 0 1 8}$ & 54.600 & $47.178,76$ & $31,07 \%$ \\
$\mathbf{2 0 1 9}$ & 53.600 & $46.314,68$ & $31,07 \%$ \\
\hline
\end{tabular}

\section{KESIMPULAN}

Dari perhitungan konversi energi dari Biomassa menjadi Energi Listrik diatas, yang menandakan Potensi Energi listrik dari Biomassa sangatlah besar sehingga didapatlah tujuan sebagai berikut:

1. Massa Syngas yang dihasilkan dari limbah padi berupa sekam padi memiliki kadar kalori yang cukup tinggi yaitu $3300 \mathrm{kKal} / \mathrm{Kg}$, dan dari kalor jenis ini bisa didapat pengkonversian energi kalor menjadi Energi listrik, yang mana Energi Listrik terhitung per $1 \mathrm{KWH}=3,6 \times 106$ Joule.

2. Pengkonversian Energi dari Biomassa menjadi listrik juga tidak terlepas dari peran serta oleh Syngas, yang mana Syngas yang terkandung didalam sekam padi adalah Carbon (CO), Hidrogen (H), Nitrogen (N), Metana(CH4).

3. Efisiensi gasifikasi sangat dipengaruhi oleh adanya High Heating Value (HHV) dan Lower Heating Value(LHV) yang didalamnya terdapat komponen syngas yang memberikan dampak besar terhadap pembakaran didalam reaktor gasifikasi yang kemudian masing masing dari HHV dan LHV akan berkolaborasi dengan Massa biomassa dan Massa syngas.

4. Pembangkit Listrik Tenaga Biomassa sangatlah cocok untuk diterapkan dibanyak daerah di Indonesia yang terutama memiliki produksi pertanian dalam skala besar, yang mana Biomassa sangat berbanding lurus dengan produksi dari padi itu sendiri.

\section{UCAPAN TERIMA KASIH}

Terima kasih kami ucapkan kepada seluruh pihak yang telah membantu Jurnal rancangan ini untuk terealisasi, yaitu kepada

1. Allah SWT, yang selalu memberikan segalannya, Kesempatan dan waktu luang kepada kami untuk terus belajar, menuntut ilmu serta menjadi lebih baik

2. Orang tua, yang selalu membersamai dan mendukung dalam suka maupun duka

3. Prodi dan dosen Teknik Elektro yang telah memberikan wadah dan bimbingan kepada kami yang telah berupaya mencerdaskan kehidupan bangsa

4. Ir. Rani Alham S.Pd., M.T selaku Dosen Mata Kuliah Energi Baru Terbarukan, yang tidak henti hentinya memberikan kami dukungan dan dorongan untuk terus berkarya dan bekerja keras dalam upaya memajukan diri dan masa depan.

5. Teman teman Elektro 2018, dalam kebersamaan menggapai cita cita dan tujuan

6. Dan seluruh pihak yang telah membantu secara dukungan dan moril yang tak bisa dijabarkan satu per satu.

Semoga Allah selalu menjaga kita semua, mempermudah segala urusan kita, dan menjadikan kita semua bertetangga di SyurgaNya kelak.

\section{DAFTAR PUSTAKA}

[1] I. Pujotomo, "Potensi Pemanfaatan Biomassa Sekam Padi Untuk Pembangkit Listrik Melalui Teknologi Gasifikasi," Energi dan Kelistrikan J. Ilm., vol. 9, no. 2, pp. 126-135, 2017.

[2] J. E. Witoyo, "Makalah Bioenergi Gasifikasi Biomassa Sekam Padi," Universitas Brawijaya Malang, 2014. 
SainETIn (Jurnal Sain, Energi, Teknologi \& Industri), Vol. 4 No. 2, Juni 2020, pp. 48 - 56

ISSN 2548-6888 print, ISSN 2548-9445 online

[3] Noviyanto, F. Amirotus, V. U. A, H. Anwar, S. Gunawan, and T. Widjaya, "Produksi Gas Metana Dari Limbah Jerami Padi Dengan Inokulasi Mikroorganisme Rumen Sebagai Sumber Energi Terbarukan," J. Tek. Kim., vol. 9, no. 2, pp. 58-61, 2019.

[4] B. P. dan P. Pertanian., "Sekam Padi Sebagai Sumber Energi Alternatif dalam Rumah Tangga Petani," Sinar Tani, Jakarta, 2008.

[5] Monice and Perinov, "Analisis Potensi Sampah Sebagai Bahan Baku Pembangkit Listrik Tenaga Sampah (PLTSa) di Pekanbaru," SainETIn J. Sains, Energi, Teknol. dan Ind., vol. 1, no. 1, pp. 9-16, 2016.

[6] S. Herodian, "Peluang dan Tantangan Industri Berbasis Hasil Samping Pengolahan Padi. Arikel," J. Pangan, vol. 16, no. 1, pp. 38-49, 2007.

[7] H. Susanto, Pengembangan teknologi Gasifikasi Untuk Mendukung Kemandirian Energi dan Industri Kimia, no. November. Bandun: ITB, 2018.

[8] E. Suhendi, G. U. Paradise, and I.
Priandana, "Pengaruh Laju Alir Udara Dan Waktu Proses Gasifikasi Terhadap Gas Producer Limbah Tangkai Daun Tembakau Menggunakan Gasifier Tipe Downdraft," $J$. Bahan Alam Terbarukan, vol. 5, no. 2, pp. 45-53, 2016.

[9] S. Prasetya.D.Y., M. Sucipta, and I. N. S. Winaya, "Perancangan Gasifikasi Dowdraft dengan Variasi Laju Aliran Oksigen Sebagai Agen Gasifikasi. Universitas Udayana. Bali.," J. Mettek, vol. 1, no. 2, pp. $1-8,2015$.

[10] G. Grassi, A. Collina, and H. Zibetta, "Biomass for Energy, Industry and Environment," in International Conference on Biomass for Energy, Industry and Environment held in Athens, Greece, 1991, p. 1464.

[11] S. Widiyanto and S. Putro, "Analisa Nilai Kalor Pengujian Bahan Bakar Biomassa Terhadap Korelasi HHV (High Heating Value)," Universitas Muhammadiyah Surakarta, 2017.

[12] Sears and Zemansky, Fisika Universitas, 10th ed. Jakarta: Erlangga, 2002. 